\title{
УЛЬТРАСТРУКТУРНІ ОСОБЛИВОСТІ ПЛАЦЕНТИ В РІЗНІ ТЕРМІНИ БЕЗВОДНОГО ПЕРІОДУ
}

\author{
(Н.П. Гончарук, Л.О. Стеченко, В.П. Лакоташ, Т.П. Куфтирєва, І.С. Іщенко
}

Національний медичний університет імені О.О. Богомольця

\begin{abstract}
РЕЗЮМЕ. Методом електронної мікроскопії досліджений ворсинчастий хоріон плаценти породіль з недоношеною вагітністю строком 33-34 тижні у різні терміни після передчасного розриву плідних оболонок (ПРПО): 1) 5-6 годин безводного періоду (контроль); 2) 30-33 години безводного проміжку; 3) 45-48 годин після витоку плідних вод; 4) 9 діб після ПРПО. Встановлено, що термінальні ворсинки 33-34 тижневих плацент в усі досліджені терміни безводного періоду (від 5-6 годин до 9 діб) мають принципово однотипну ультраструктурну організацію, головними компонентами яких є синцитіотрофобласт, цитотрофобласт та його похідний - фібриноїд, кровоносні мікросудини. Прогресування ультраструктурних змін в усіх цих структурах відбувалося поступово в динаміці пролонгування безводного періоду і мало, як правило, зворотний характер. Відсутність імунокомпетентних клітин в термінальних ворсинках в усі терміни спостережень свідчить про те, що при подовженому безводному періоді не відбувається поширеності інфекції та розвитку запальних і аутоімунних процесів у плаценті. Отримані дані можуть бути теоретичним підгрунтям вибору тактики ведення пологорозродження після ПРПО при недоношеній вагітності.

КЛЮчОВІ СлОВА: плацента, передчасний розрив плідних оболонок, електронна мікроскопія.
\end{abstract}

Вступ. Проблема ведення вагітності при передчасному розриві плідних оболонок (ПРПО) не втратила своєї актуальності. До тепер не існує єдиної точки зору скільки часу може тривати безводний період. Особливо гостро постає це питання при передчасних пологах, коли необхідно чітко визначити доцільність і тривалість пролонгування вагітності, профілактику можливих ускладнень, спосіб пологорозродження [3]. Одні акушери вважають, що зростання лейкоцитозу у периферійній крові вагітних з ПРПО, підвищення температури тіла є достатніми симптомами для діагностики хоріоамніоніту та стимуляції пологів. Однак інші дані свідчать, що найвищі показники лейкоцитозу, які визначаються протягом першої доби безводного проміжку, поступово зменшуються і на третю добу знаходяться у межах норми [2]. Разом з тим, пролонгування вагітності дозволяє підготувати легені, а точніше систему легеневого сурфактанту, недоношеного плода до позаутробного існування [4]. При передчасних пологах неонатальна смертність становить > 30 \% саме від респіраторного дістрес-синдрому [5]. Слід відмітити, що більшість даних отримано за допомогою клінічних методів досліджень, лише окремі роботи стосуються морфології плаценти при недоношеній вагітності в безводний період [1]. Відомостей, що відбувається при недоношеності у термінальних ворсинках плаценти при передчасному розриві плідних оболонок на субклітинному рівні, нами не знайдено.

Мета дослідження - встановити ультраструктурні особливості термінальних ворсинок плаценти в різні терміни після ПРПО при недоношеній вагітності.

Матеріал та методи дослідження. Матеріалом для електронно-мікроскопічного дослід- ження був ворсинчастий хоріон посліду породіль з недоношеною вагітністю строком 33-34 тижні у різні терміни після ПРПО. Досліджено 4 групи жінок: 1 група - жінки, безводний період у яких тривав 5-6 годин і які складали контрольну групу; 2 група - жінки з 30-33 годинами безводного проміжку; 3 група - 45-48 годин після витоку плодових вод; 4 група - 9 діб після ПРПО. Всього досліджено 12 жінок.

Матеріал після подрібнення фіксували у 2,5 \% розчині глютарового альдегіду на фосфатному буфері на протязі 1 години з наступною дофіксацією OsO4 за Мілонінгом. Матеріал зневоднювали та заключали у суміш епону та аралдиту згідно з загальноприйнятими електронномікроскопічними методиками. Після попередньої ідентифікації на напівтонких зрізах, забарвлених толуїдиновим синім, виготовлялися ультратонкі зрізи, які контрастували уранілацетатом та цитратом свинцю. Матеріал вивчали в електронному мікроскопі ПЕМ-125К та фотографували при збільшеннях 4-12 тисяч раз.

Результати й обговорення. Електронномікроскопічно встановлено, що через 5-6 годин безводного періоду термінальні ворсинки 33-34 тижневих плацент мають типову для цього терміну вагітності будову. Вони вистелені одношаровими багатоядерними клітинами - синцитіотрофобластами, які в різних ділянках мають ультраструктурні особливості. Ядра в цих клітинах, як правило, утворюють скупчення, але зустрічаються й ядра розташовані поодинці. Всі ядра в синцитіотрофобластах містять функціонально неактивний гетерохроматин у вигляді конгломератів біля нуклеолеми. На люмінальній поверхні синцитіотрофобластів спостерігаються розгалужені мікроворсинок, кількість яких варіює. Ци- 
Оәляди літератури, оригінальні дослідження, погляд на проблему, короткі повідомлення, замітки з практики

топлазма заповнена переважно канальцями зернистої ендоплазматичної сітки, будова яких надає синцитіотрофобластам ультраструктурні особливості. Подекуди канальці невеликі за розмірами з незначним міжмембранним простором, подекуди вони значно розширені і мають вигляд вакуолей, частина яких нерівномірно заповнена електроннощільним матеріалом. Але переважають в синцитіотрофобластах помірно розширені канальці (рис. 1 А). Все це відображає різний функціональний стан та ступінь зрілості цих клітин. Досить часто синцитіотрофобласт контактує з цитотрофобластами, так званими клітинами Ланганса. Останні демонструють ультраструктурні ознами функціональної активності: в ядрах рівномірно розташований функціонально активний еухроматин; цитоплазма заповнена канальцями зернистої ендоплазматичної сітки, рибосомами, полісомами, мітохондріями (рис. 1 А, Б). Кровоносні мікросудини плацентарного бар'єру досить щільно прилягають як до синцитіотрофобласту, так і до цитотрофобласту. Перикапілярного набряку не спостерігається. Просвіт гемомікросудин заповнений дрібнодисперсним матеріалом помірної електронної щільності, подекуди еритроцитами. Ендотеліальні клітини, які вистеляють мікросудини, переважно без дистрофічно-деструктивних змін, містять канальці зернистої ендоплазматичної сітки, мітохондрії, рибосоми, полісоми, секреторні гранули (рис.1 Б).

Через 30-33 години безводного періоду електронно-мікроскопічно в термінальних ворсинах посліду породіль виявляється синцитіотрофобласт у вигляді багатоядерних структур, які

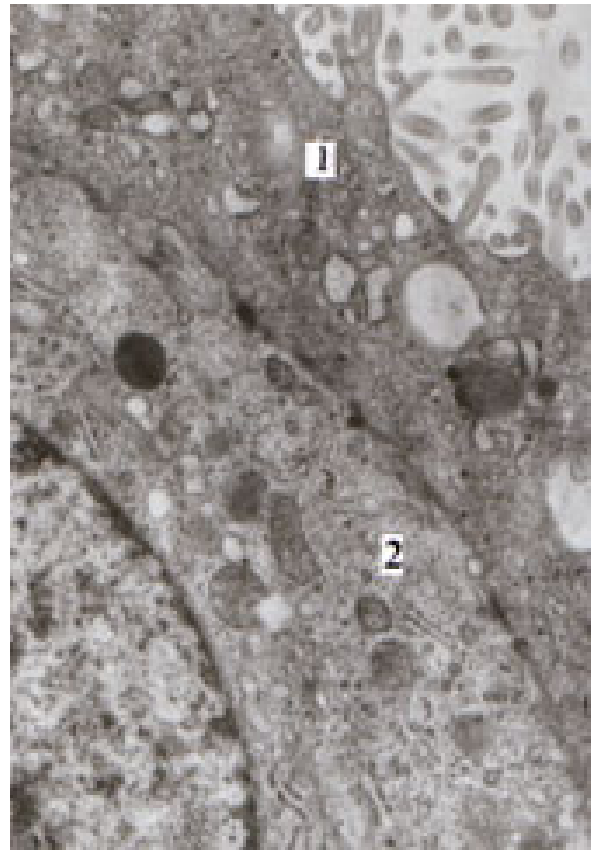

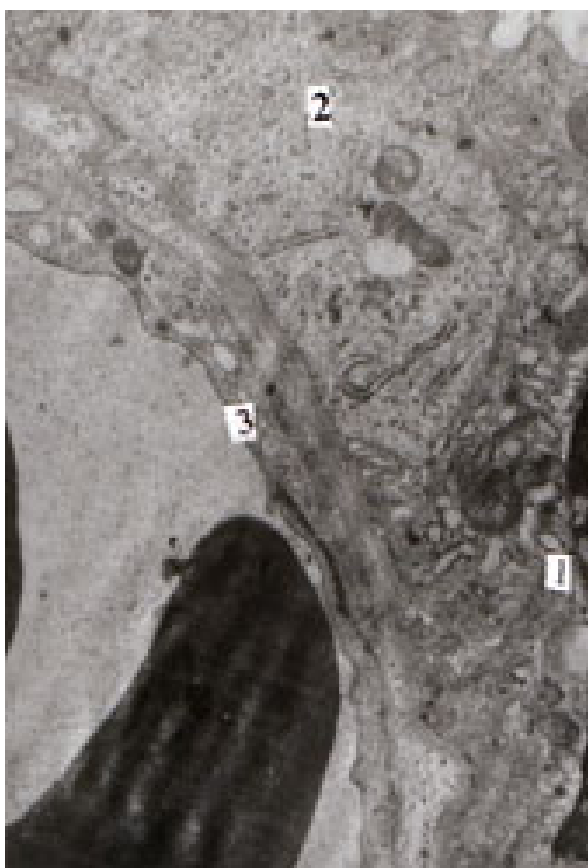

Б

Рис. 1. Фрагменти термінальних ворсинок плаценти хворої А. через 5 год безводного періоду. Синцитіотрофобласт (1), цитотрофобласт (2), ендотеліоцит (3). А - 9600, Б - 4800

розміщені у один шар та мають велику кількість різноманітних за формою мікроворсинок - від тонких мікровиростів до випинань ділянок цитоплазми (рис. 2 А). В ядрах синцитіотрофобласту переважає гетерохроматин, розміщений маргінально. У цитоплазмі розміщуються вакуолі, які за розміром, будовою та вмістом помірної електронної щільності подібні до описаних у попередній строк (рис. 2 А). До синцитіотрофобласту прилягяють досить великих розмірів клітини цитотрофобластами. Вони містять функціонально активне ядро з ядерцями та характеризуються добре розвиненою зернистою ендоплазматичною сіткою, яка власне бере участь у формуванні фібриноїду (рис. 2 Б). Для цих клітин характерна наявність великої кількості надто тонких фібрил, які завдяки конформаційним перебудовам перетворються у компоненти фібриноїду, який може частково накопичуватися як у цитоплазмі цих клітин, так і за їх межами (рис. 2 Б). Мітохондрії представлені у незначній кількості і надто малими за розмірами (рис. 2 Б). Ймовірно, енергопостачання цих клітин в значній мірі відбувається за рахунок присутнього тут глікогену. У великій кількості представлені лізосоми - від первинних до фагосом (рис. 2 Б). У місцях контакту цитоплазма синцитіотрофобласту і ендотеліоцитів суттєво стоншується. Кровоносні капіляри мають ядро з маргінально розташованим гетерохроматином. Органели 

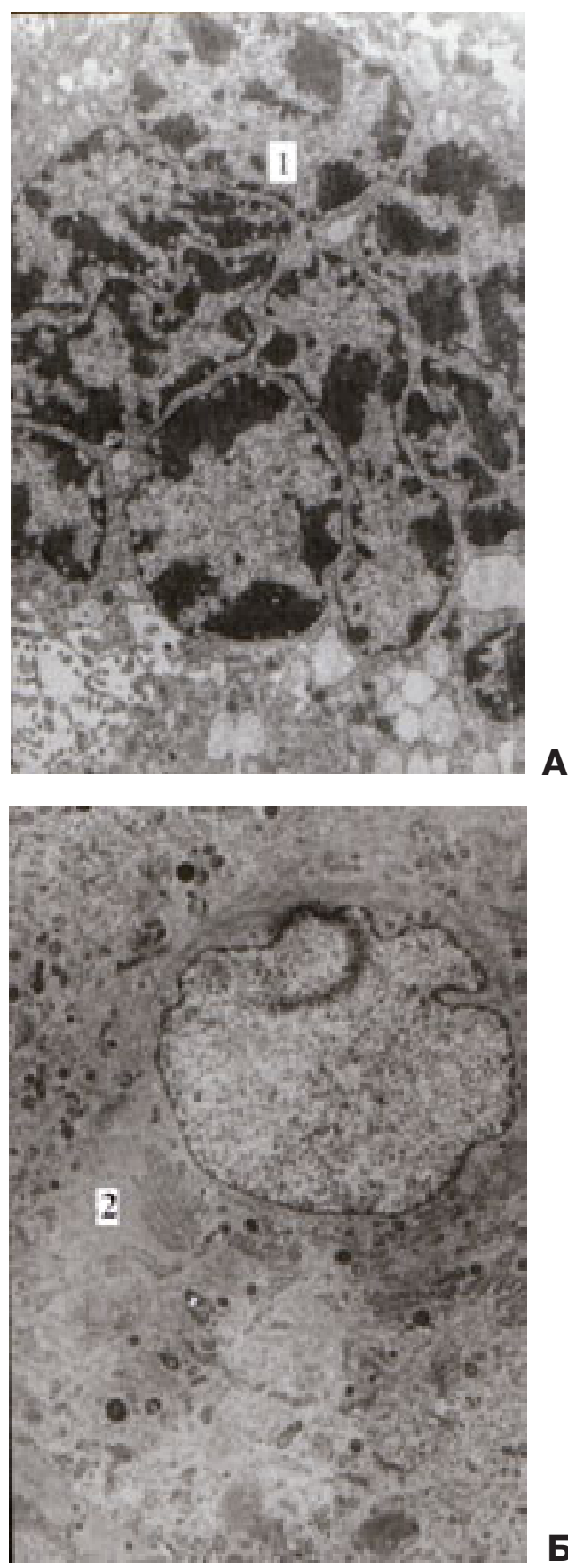

Рис. 2. Фрагменти термінальних ворсинок плаценти хворої К. через 33 год безводного періоду. Синцитіотрофобласт (1), цитотрофобласт (2).

A - 4800, Б - 3200

біосинтетичного плану представлені у незначній кількості, тоді як мікрофіламенти майже повністю заповнють окремі ділянки цитоплазми. Просвіт мікросудин виповнений помірної щільності плазмою та еритроцитами.

На 45 годину безводного періоду термінальні ворсинки плаценти покриває одношаровий багатоядерний синцифіотрофобласт, розміщений на базальній мембрані. Мікроворсинки дещо десквамовані, мають вигляд витягнутих трубочок або округлих структур (рис. 3 А). Їх кількість значно менша, ніж у ворсинках через 5-6 годин безводного періоду, тобто контролю. В ядрах, як і в попередній термін спостережень, відмічається маргінальне розміщення гетерохроматину та наявність великої кількості вакуолей, серед яких зустрічаються вакуолі досить великих розмірів. Більшість цих структур має вміст помірної електронної щільності. В цитоплазмі розташовуються ліпідні та глікогенові включення, кількість яких в цей період незначна. В деяких ворсинках синцитіотрофобласт безпосередньо контактує з фібриноїдом Ланганса та цитотрофобластом. У зоні гематоплацентарного бар'єру синцитіотрофобласт значно стоншується, контактує з підлеглою сполучною тканиною, яка, в свою чергу, прилягає до базальної мембрани ендотелію кровоносних капілярів. У лакулярних порожнинах, крім формених елементів, подекуди спостерігається клітинний детрит частково десквамованого синцитіотрофобласта (рис. 3 А). Клітини Ланганса в цілому мають типову для них будову, хоча спостерігається незначний відсоток дистрофічно змінених цитотрофобластів. Для останніх характерним є цитоліз, локальний набряк мітохондрій, розширення канальців ендоплазматичної сітки та фігури мієлінової дегенерації (рис.3 Б). Цікавим є транспонтування ендотеліоцитами надлишків глікогену. Глікоген, накопичений у цитотрофобластах, частина з яких виконавши свою функцію, залишає лише фрагменти цитоплазми з надлишками глікогену, потім трансендотеліально надходять у кровоносне русло у вигляді вакуолей, що "відшнурувалися" від цитоплазми ендотеліоцитів.

Незначна кількість судин гемомікроциркуляторного русла мають пошкодження, які свідчили про наявність в цей термін спостережень гіпоксичних та ішемічних змін, які розвинулись на фоні компенсаторно-адаптивних процесів. До останніх можна віднести стоншення ендотелію 3 метою більш ефективного переносу речовин. 3 іншого боку, у просвітах деяких мікросудин спостерігався сладж-феномен, тобто скупчення еритроцитів та тромбоцитів аж до утворення тромбу.

Через 9 діб безводного періоду термінальні ворсинки мали всі описані вище ультраструктури: синцитіотрофобласт, цитотрофобласти з прилеглим фібриноїдом, кровоносні мікросудини. Відмінністю від попередніх термінів спостережень було збільшення електронної щільності цитоплазми синцитіотрофобласту, яке відбувалося на фоні редукції мікроворсинок, збільшення гетерохроматину в ядрах, патологічного роз- 
Оәляди літератури, оригінальні дослідження, погляд на проблему, короткі повідомлення, замітки з практики

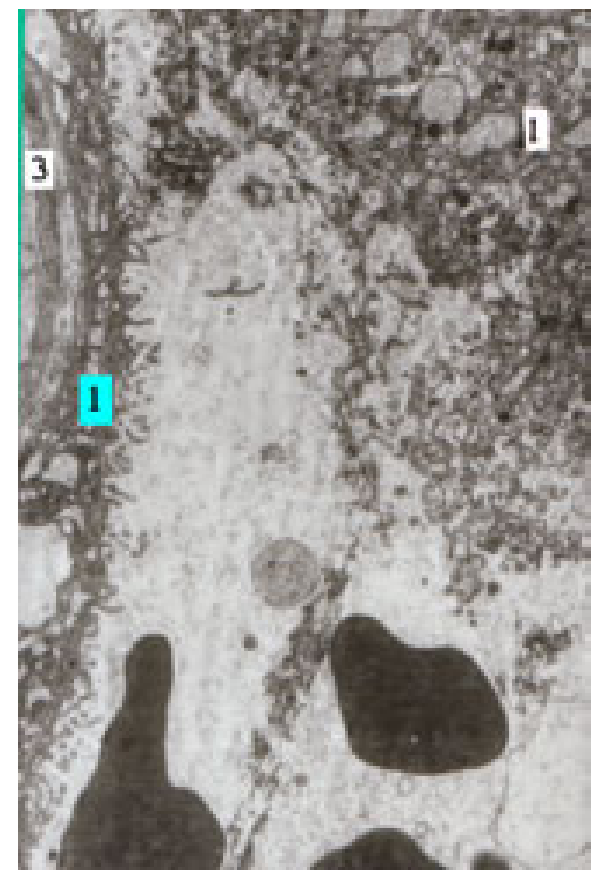

A

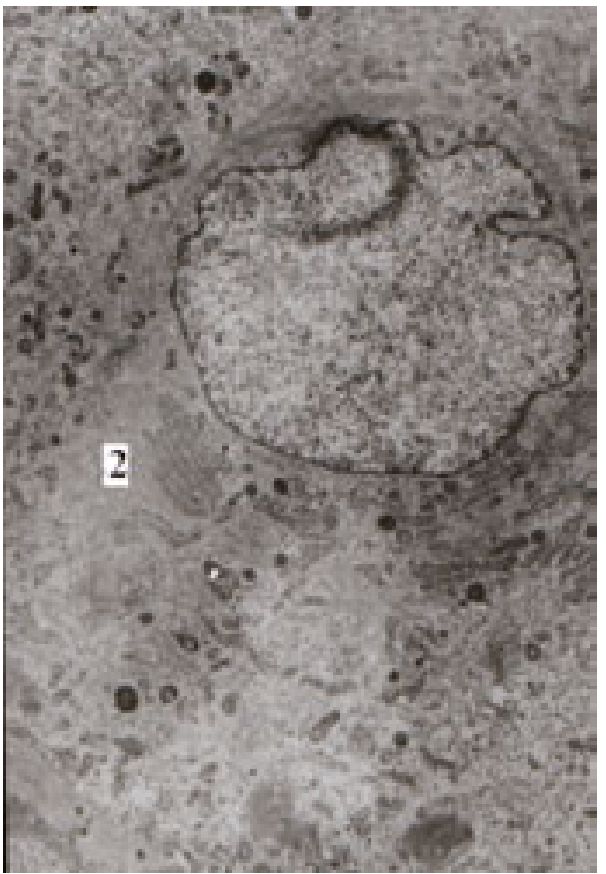

Б

Рис. 3. Фрагменти термінальних ворсинок плаценти хворої Г. через 45 год безводного періоду. Синцитіотрофобласт (1), цитотрофобласт (2), ендотеліоцит (3). А - 6400, Б - 8000

ширення канальців зернистої ендоплазматичної сітки (рис. 4 А). Тоді як синцитіотрофобласти змінювалися за темним типом, то для цитотрофобластів характерним було просвітлення цитоплазми, що було скоріше усього ультраструктурним проявом їх набряку (рис. 4 Б). Ділянки локального набряку спостерігалися також в ендотеліальних клітинах гемомікросудин загалом

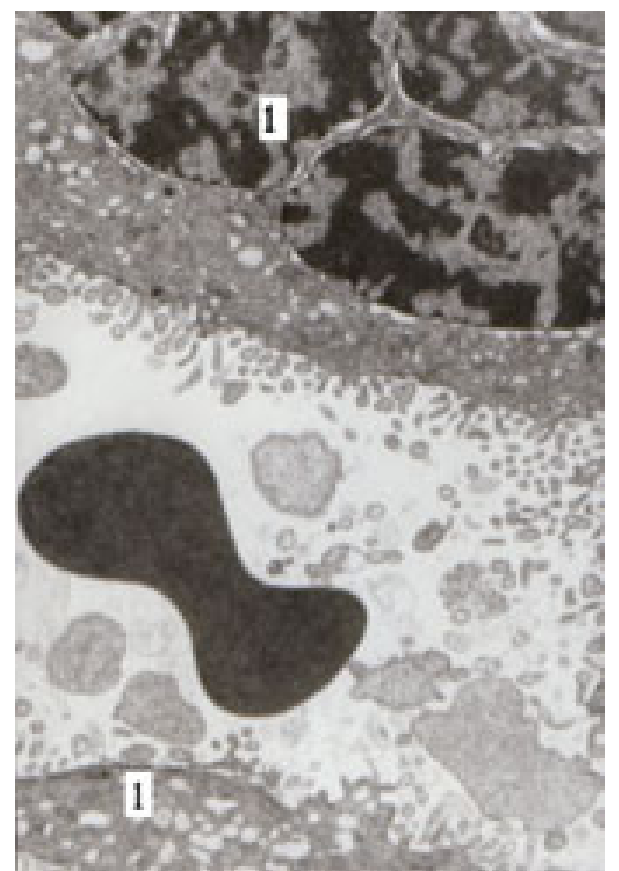

A

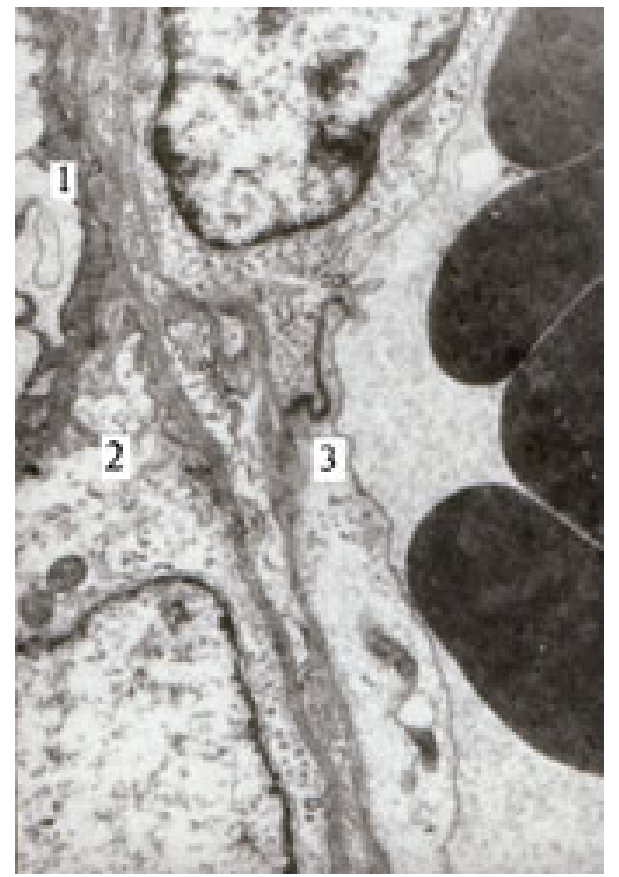

Б

Рис. 4. Фрагменти термінальних ворсинок плаценти хворої С. через 9 діб безводного періоду. Синцитіотрофобласт (1), цитотрофобласт (2), ендотеліоцит (3). А - 6400, Б - 8000

і їх мітохондріях зокрема. Характерним була підвищена кількість гетерохроматину в ядрах та міофібрил в цитоплазмі ендотеліоцитів порівняно 3 попередніми термінами спостережень (рис. 4 Б). Разом з тим, ознак виразних деструктивних процесів в термінальних ворсинках не спостерігалося, хоча і відмічався подекуди в лакунах клітинний детрит ( рис. 4 А). Відсутня була 
й лейкоцитарна інфільтрація, яка б свідчила про розвиток запальних процесів у посліді.

Таким чином, до 9 доби безводного періоду спостерігається збереженність цілісності термінальних ворсинок як в цілому, так і окремих їі компонентів. Деякі з них зазнають незначних змін, більшою мірою це належить до гемомікроциркуляторного русла, яке функціонує у режимі незначного перевантаження.

Висновки. 1. Термінальні ворсинки 33-34 тижневих плацент в усі досліджені терміни безводного періоду (від 5-6 годин до 9 діб) мають принципово однотипну ультраструктурну організацію, головними компонентами яких є синцитіотрофобласт, цитотрофобласт та його похідний фібриноїд, кровоносні мікросудини.

\section{ЛІТЕРАТУРА}

1. Дрінь Т.М. Морфологічні зміни посліду при недоношуванні вагітності у жінок з передчасним розривом амніональних оболонок // Галицький лікарський вісник. - 2002. - Т. 9, № 1. - С. 43-46.

2.Дрінь Т.М. Клініка і тактика ведення недоношеної вагітності у жінок з передчасним розривом амніональних оболонок // Педіатрія, акушерство та гінекологія. - 2002. - № 4. - С. 66-70.

3. Growley P., Chalmers I., Keirse M.J. The effects of corticosteroid administration before preterm delivery: an
2. Прогресування ультраструктурних змін в синцитіотрофобласті, цитотрофобласті та кровоносних мікросудинах відбувалося поступово в динаміці пролонгування безводного періоду і носило, як правило, зворотний характер.

3. Відсутність лейкоцитарної інфільтрації в термінальних ворсинках в усі терміни спостережень свідчить про те, що у плаценті при подовженому безводному періоді не відбувається поширеності інфекції і розвитку запальних та аутоімунних процесів.

Перспективи подальших досліджень. Отримані дані можуть бути теоретичним підгрунтям вибору тактики ведення пологорозродження після ПРПО при недоношеній вагітності.

overview of the evidence from controlled trials // Br. J. Obstet. Gynecol. - 1990. - V. 97. - P. 11-25.

4. Healy A.J., Veille J.C., Sciscionee A. et al. The timing of elective delivery in preterm premature rupture of the membranes: A survey of Members of the Society of Maternal-Fetal Medicine // Am. J. Obstet. Gynecol. - 1998. - V. 179. - P. 94-99.

5. Spencer C., Neales K. Antenatal corticosteroids to prevent neonatal respiratory distress syndrome // BMJ. 2000. - V. 320. - P. 325-326.

\title{
ULTRASTRUCTURAL PECULIARITIES OF PLACENTA IN DIFERENT TERMS OF AMNION WATERLESS PERIOD
}

\author{
C)N.P. Honcharuk, L.O. Stechenko, V.P. Lakotash, T.P. Kuftyreva, I.S. Ishchenko \\ National Medical University by O.O. Bohomolets
}

SUMMARY. Placenta was investigated by electron microscope method with premature pregnancy under different terms after fetal involucres precondition disruption: 1) 5-6 hours of waterless period (control); 2) 30-33 hours of waterless period; 3) 45-48 hours of waterless period; 4) 9 days of waterless period. We found equal ultrastructural features of end villas in all study groups. They are syncytiotrophoblast, cytotrophoblast and its derivative - fibrinoid tissue and blood microvessels. Ultrastructural change increased in dynamics of waterless period prolongation. They have been flexible. We didn't find immune cells in terminal villas in all investigated groups. It suggests absence of inflammation and autoimmunity processes in placenta during prolonged waterless period. These data are theoretical base for choice of medical tactics at premature delivery after fetal involucres precondition disruption.

KEY WORDS: placenta, fetal involucres precondition disruption, electron microscopy. 